\title{
Application of remote methods for landscape taxation of forest-park forests
}

\author{
Oleg Artemjev ${ }^{1}$ and Larisa Baykalova ${ }^{2}$ \\ ${ }^{1}$ Reshetnev Siberian State University of Science and Technology, 660037 Krasnoyarsk Russia \\ ${ }^{2}$ Krasnoyarsk state agrarian University, 660049 Krasnoyarsk Russia
}

\begin{abstract}
Here provided are developed methodologies of landscape taxation of forest-park forests, based on the use of remote sensing methods. The methods of decoding by aerospace photographs of a walking road-path network and recreational forest digression are described. Methods, which are using terrestrial images, will improve the accuracy of assessment of landscape and architectural indicators: the closure of the canopy of the tree stand, the assessment of the aesthetics of the site, the passability of the terrain of the site, sanitary and hygienic assessment.
\end{abstract}

\section{Introduction}

Forest park forests are among the most valuable categories of forest and as a result, development to improve their inventory is relevant. The use of remote methods for taxation of forest-park forests will increase the accuracy of their assessment.

\section{Suggested landscape inventory techniques}

Forest park forest attendance is more dependent on the existence of a walking road-trail network.

The design of a walking road-path network should be given special attention, since errors in its design will not only reduce the attendance of the recreation object, but also cause unreasonable costs for the construction of those walking roads and paths that will be not enough visited.

To improve the design quality of the walking road-path network, the following methods is proposed: At the first stage, using the color spectrozonal aerial photographs or color spectral satellite photographs, the existing road-path network is decrypted. It is necessary to use large-scale aerospace photographs. Decryption of roads is straightforward and is carried out according to existing methods. Deciphering of walking trails is based on direct and

\footnotetext{
${ }^{1}$ Corresponding author: ol.artemjev2010@yandex.ru
} 
indirect decoding attributes developed by the author using stereopairs of aerospace photographs [1]. Descriptions of the decryption features are shown in Table 1.

Table 1. Deciphering signs of walking trails.

\begin{tabular}{|c|c|c|c|c|}
\hline \multicolumn{4}{|c|}{ Deciphering signs of walking trails } \\
\hline Shape & Color & $\begin{array}{c}\text { Spatial placement } \\
\text { with stereoscopic } \\
\text { perception }\end{array}$ & $\begin{array}{c}\text { Proximity to } \\
\text { public places of } \\
\text { rest, public } \\
\text { transport, houses, } \\
\text { roads }\end{array}$ & $\begin{array}{c}\text { Closed forest } \\
\text { canopy }\end{array}$ \\
\hline $\begin{array}{c}\text { Thin, } \\
\text { interconnected } \\
\text { lines, in stands } \\
\text { with high } \\
\text { closeness - } \\
\text { dashed lines }\end{array}$ & $\begin{array}{c}\text { On dark gray to } \\
\text { black lands } \\
\text { covered with } \\
\text { forest; on } \\
\text { uncovered - the } \\
\text { same as the } \\
\text { surrounding } \\
\text { area, but lighter }\end{array}$ & $\begin{array}{c}\text { Trail trails are } \\
\text { below the canopy } \\
\text { of the stand }\end{array}$ & $\begin{array}{c}\text { Most trails are } \\
\text { near objects of } \\
\text { mass visit }\end{array}$ & $\begin{array}{c}\text { Most paths go } \\
\text { through less } \\
\text { densely forested } \\
\text { stands. }\end{array}$ \\
\hline
\end{tabular}

In addition to decryption features, the use of "standards" is recommended, such as stereo pairs of images with an already decrypted path network.

The number of identified paths in aerial photographs of various scales is shown in the Table 2 .

Table 2. The number of identified paths in aerial photographs of various scale.

\begin{tabular}{|c|c|c|c|c|}
\hline \multirow{2}{*}{$\begin{array}{c}\text { Length paths } \\
\text { (according to } \\
\text { ground survey), } \\
\mathrm{km}\end{array}$} & \multicolumn{3}{|c|}{ Of these, identified on scale aerial photographs } \\
\cline { 2 - 5 } & км & $\begin{array}{c}\text { \% of the total } \\
\text { length of paths }\end{array}$ & \multicolumn{2}{c|}{$1: 3000$} \\
\cline { 2 - 5 } & 79,45 & 93,4 & 80,89 & $\begin{array}{c}\% \text { of the total } \\
\text { length of paths }\end{array}$ \\
\hline 85,06 & 79,1 \\
\hline
\end{tabular}

The difference in estimating the length of walking roads according to the existing methodology and according to the proposed one is $6.6 \%$ and $4.9 \%$. In taxation, such a difference is considered acceptable

During the field period, a ground survey of the road and trail network is carried out. During the examination, the road-tropine network diagram shall be checked and corrected, if necessary, based on the decryption data. At the same time, this scheme includes paths not identified on aerial photographs, for which purpose points are taken on the track of the unknown trail after 30 meters, the location of it on the aerial photograph or space photograph is located by linking it to the elements of the visible area on the picture. The found points are applied to the snapshot and connected to each other, forming the path of the trail. 
To assess the quality of paths and roads, their width and type of coverage are determined by the elements. As the element of the path network means a section of the path from one intersection of the path with another path or road to the next intersection. In addition, a visual assessment of the elements of the walking path network is made according to 3 scales: on the scale for assessing the aesthetics of the surrounding forest park landscape paths (according to N.M. Tyulpanov) [2], on the scale for assessing the load of the path network $[1 ; 3]$ and on the scale for assessing the patency of the path network $[1 ; 3]$.

At the second stage, the obtained data on the area of the road-path network are compared with the normative. If according to the inventory data the area of the road-path network exceeds the normative, then part of the paths is not included in the designed roadpath network, in that way, work on their improvement will not be carried out on these paths. First of all, are excluded the paths passing through the territory with stages fourth and fifth of recreational digression of the forest (the areas most affected by the recreational load), and the trails with the lowest scores on the scales. At the same time, it is necessary to ensure that the exclusion of elements of the path network does not disconnect the other elements. All roads are included in the design of the road-path network. The exclusion of the elements of the path network is made until the area of the road and path network becomes normative.

In the event that the area of the existing walking road and path network is less than normative, it is recommended to initially design objects of mass visits (beaches, recreation areas, etc.), and only then design new roads to it.

When landscape taxation of forest-park forests is assessed, such a landscapearchitectural indicator as recreational digression of the forest. To increase accuracy and reduce the cost of landscape taxation of this landscape-architectural indicator, a technique was developed for its interpretation by aerospace photographs. Deciphering signs of recreational digression of the forest are shown in Table 3.

Table 3. Decoding signs of the stages of recreational digression of the fores.

\begin{tabular}{|c|c|c|c|c|}
\hline \multirow[t]{2}{*}{ Decryption features } & \multicolumn{4}{|c|}{ Stages of recreational forest digression } \\
\hline & I & 2 & 3 & 4 \\
\hline $\begin{array}{l}\text { 1. Location of the } \\
\text { surveyed area }\end{array}$ & $\begin{array}{l}\text { in depth } \\
\text { the wood }\end{array}$ & intermediate & \multicolumn{2}{|c|}{$\begin{array}{c}\text { near objects of mass } \\
\text { recreation }\end{array}$} \\
\hline $\begin{array}{l}\text { 2. Road and Trail } \\
\text { Network: } \\
\text {-area } \\
\text { - location density } \\
\text { - assessment of the } \\
\text { load of paths } \\
\text {-assessment of cross- } \\
\text { country path }\end{array}$ & $\begin{array}{c}- \\
- \\
\text { I point } \\
1 \text { point }\end{array}$ & $\begin{array}{c}<5 \% \\
\text { rare } \\
1-2 \text { point } \\
1-2 \text { point }\end{array}$ & $\begin{array}{c}<8 \% \\
\text { intermediate } \\
3 \text { point } \\
2-3 \text { point }\end{array}$ & $\begin{array}{c}<15 \% \\
\text { branched } \\
4 \text { point } \\
3 \text { point }\end{array}$ \\
\hline $\begin{array}{l}\text { 3. Series } \\
\text { forest park } \\
\text { landscap }\end{array}$ & 16 & $16,1 \mathrm{a}$ & $1 \mathrm{a}, 26$ & $2 \mathrm{a}$ \\
\hline
\end{tabular}




\begin{tabular}{|l|l|l|l|l|}
\hline $\begin{array}{c}\text { 4. Placement of small } \\
\text { architectural forms }\end{array}$ & not & not & there is & there is \\
\hline $\begin{array}{c}\text { 5. Undereatage and } \\
\text { undergrowth }\end{array}$ & & uniform & intermediate & group \\
\hline
\end{tabular}

The difference in the assessment of recreational forest digression according to the existing methodology and according to the proposed one is given in Table 4.

Table 4. Comparison of the interpretation data of the stages of recreational digression of the forest with data obtained by the method of N. S. Kazanskaya [3].

\begin{tabular}{|c|c|c|c|c|}
\hline \multirow{2}{*}{$\begin{array}{c}\text { Stage of } \\
\text { recreational } \\
\text { forest digression }\end{array}$} & \multicolumn{2}{|c|}{ Area, ha, defined } & \multicolumn{2}{c|}{ Distinction $\left(\mathrm{P}_{1}-\mathrm{P}_{2}\right)$} \\
\cline { 2 - 5 } & $\begin{array}{c}\text { by decryption } \\
\left(\mathrm{P}_{1}\right)\end{array}$ & $\begin{array}{c}\text { forestry } \\
\text { methodology } \\
\left(\mathrm{P}_{2}\right)\end{array}$ & ha & \\
\hline 1 & - & - & - & \\
\hline 2 & 769,39 & 778,6 & $-9,21$ & $-1,18$ \\
\hline 3 & 127,95 & 119,3 & $+8,65$ & $+7,55$ \\
\hline 4 & 0,56 & - & $+0,56$ & - \\
\hline
\end{tabular}

The difference in the assessment of the areas of recreational forest digression determined by decoding aerospace photographs does not exceed $7.55 \%$. In landscape taxation, when assessing indicators using the eye method, such a difference is considered acceptable.

Currently, landscape-architectural indicators in landscape taxation are evaluated by ocular method $[2 ; 3]$. The use of remote methods will increase the information content and accuracy of the assessment of forest parks. For this, a technique using ground digital images is proposed

During the on-site inspection of the territory in accordance with the existing methodology, three landscape-architectural indicators were assessed: landscape aesthetics, sanitary-hygienic assessment and patency of the surveyed forest-taxation site.

Taxation was carried out using the ocular method. To assess the landscape-architectural indicators, the scales used in landscape taxation were used $[2 ; 3]$.

Simultaneously with the assessment of landscape-architectural indicators, a groundbased survey of the examined sections with a digital camera was carried out.

In order to know in office conditions which section is depicted in the image, information was recorded about each examined section. The shooting location was chosen so as not to shoot against the sun. Digital images on 58 sites were taken.

In the cameral period, by studying the images of the surveyed areas on a computer monitor, landscape-architectural indicators were evaluated.

The difference in the assessment of landscape and architectural indicators by the existing methodology and by the proposed one is given in the table 5 .

Table 5. The accuracy of the assessment of landscape and architectural indicators. 


\begin{tabular}{|c|c|c|c|c|c|c|c|c|c|c|}
\hline \multirow{2}{*}{ Method of taxation } & \multicolumn{7}{|c|}{$\begin{array}{c}\text { Quantity of areas, pieces } \\
\text { aesthetic } \\
\text { class of } \\
\text { forest park } \\
\text { landscape }\end{array}$} & \multicolumn{7}{c|}{$\begin{array}{c}\text { passability } \\
\text { of area }\end{array}$} & \multicolumn{2}{c|}{$\begin{array}{c}\text { sanitary and hygienic } \\
\text { assessment }\end{array}$} \\
\cline { 2 - 13 } & 1 & 2 & 3 & good & average & high & high & average & weak \\
\hline \multicolumn{2}{|c|}{ Existing } & 24 & 25 & 9 & 14 & 21 & 23 & 13 & 24 & 21 \\
\hline \multicolumn{2}{|c|}{ Proposed } & 25 & 25 & 8 & 16 & 19 & 23 & 11 & 26 & 21 \\
\hline \multirow{2}{*}{ Difference } & pieces & 1 & 0 & 1 & 2 & 2 & 0 & 2 & 2 & 0 \\
\cline { 2 - 12 } & $\%$ & 7 & 0 & 11 & 14 & 18 & 0 & 15 & 14 & 0 \\
\hline
\end{tabular}

An analysis of the data given in the table showed that the maximum deviation in the assessment of landscape-architectural indicators is $18 \%$ (when assessing the average crosscountry ability). The average deviation in assessing the aesthetics class of the forestlandscape landscape is $6.0 \%$, in assessing the patency of the site $-10.6 \%$, and in the sanitary-hygienic assessment $-9.6 \%$ [4]. In taxation, when evaluating indicators using the eye method, such a difference is considered acceptable.

In addition, when designing events in forest park forests, it is obvious that a digital image of the highlight will be more informative for the designer than, for example, assessing its aesthetics on a three-point scale.

In order to estimate such a landscape and architectural indicator as the closure of the tree bed, images obtained during the shooting of the floor from the ground were used, the optical axis of the camera was directed vertically upwards. Then, using the electronic planimeter, the area of the crowns was calculated and the canopy closeness was calculated. Simultaneously with the shooting, the canopy closeness was assessed visually. Comparison of the data on the canopy closeness obtained by eye and according to the proposed methodology showed that the difference in average values is insignificant and amounts to 0.08 units. In landscape taxation, when assessing landscape-architectural indicators using the eye method, such a difference is considered acceptable.

\section{Conclusion}

The proposed methods for designing a walking road-path network and assessing recreational forest digression using aerial photographs will improve the quality of landscape taxation.

Assessment of landscape-architectural indicators: aesthetics of the landscape, sanitaryhygienic assessment, patency of the examined forest taxation area and closeness of the canopy of the forest stand, made according to the proposed methodology, based on the interpretation of digital terrestrial photographs using a computer, increases their information content and reliability. 


\section{References}

1. O.S.Artemjev, Methods of taxation of urban plantings (SibGTU, Krasnoyarsk, 2003)

2. N.M.Tulipov. Forest park economy: textbook. allowance (Stroyizdat, L., 1975)

3. O.S.Artemjev, R.N.Matveeva, O.F.Butorova. [and others.] Forestry basics in forest parks (VNIItslesresurs, M, 1999)

4. O.S.Artemjev Forest J. 4, 137-139 (2011) 